Brit. J. vener. Dis. (1965), 41, 66.

\title{
BULLETIN OF THE IUVDT
}

\author{
MEETING OF THE EXECUTIVE COMMITTEE
}

April 13, 14, 1964 at the Institut Alfred Fournier, Paris

(1) Dr A. J. King, President of the Union occupied the Chair and those present were Dr C.S. Nicol and Dr B. Webster (Vice-Presidents), Prof. G. A. Canaperia (Secretary-General), Dr A. Perdrup (Director, Regional Office for Europe), Dr G. Tassi (Treasurer of the Union), Dr P. Durel and Dr C. J. Alarçon (Technical Counsellors), and Madame $M$. Huet-Troué (Administrative Secretary). Also present were $\mathrm{Dr} F$. Norton-Brandao, representing the Minister of Health for Portugal, and Dr J. L. de Vries, of the World Health Organization.

In the absence of Dr Sicard de Plauzoles through illness, Medical Inspector-General Jame, Secretary-General of the French National League against the Venereal Peril, welcomed the members of the Executive Committee to the Alfred Fournier Institute. He wished them all success in the work they were now beginning. Dr King thanked InspectorGeneral Jame and asked him to convey to Dr Sicard de Plauzoles his good wishes, as well of those of his colleagues, for a complete and early recovery. $\mathrm{He}$ expressed the great pleasure of the Executive Committee that their meeting was held at the Institute. Dr King also thanked Dr Durel for organizing the meeting and expressed his warm gratitude to Madame Huet-Troué for her never-failing loyalty and help.

He read messages of regret from Mrs J. Tuller, Dr A. Cavaillon, Dr W. J. Brown, and Dr J. Cutler who were unable to be present. Dr T. Guthe intended to be present but was unable to do so and nominated his colleague, Dr J. L. de Vries as his deputy.

\section{(2) Report of the Secretary-General}

The Agenda was approved and the SecretaryGeneral then described the activities of the Union from June, 1963, which was the date of the last meeting of the Executive Committee in Copenhagen, up to April, 1964.

The minutes of the General Assembly held in Washington in 1962, as well as those of the last Executive Committee Meeting, had been sent to all members, In addition, the drafts of the new statutes had been prepared in French and English and had been distributed; copies were available from the Secretariat. The second number of the International Bulletin of the IUVDT had been published in the March, 1964 number of the British Journal of Venereal Diseases. The Bulletin included the President's report, the minutes of the meeting held at Copenhagen in 1963, and the report presented by the Union at the 16th Assembly of the World Health Organization in May, 1963. Copies would, as before, be sent to all members of the Union. As regards recruitment of individual members, the Secretariat had prepared a brochure in French and in English and specimens of these were available for members to examine.

A European Seminar on the subject of venereal diseases had been organized by the European Regional Office of WHO in Stockholm in October, 1963. The Union had been represented at this important meeting by the President, Dr King, and by Drs Perdrup and Tottie. The Secretary-General had represented the Union at the last meeting of the WHO Executive Committee in January, 1964, and at the 17th Assembly of WHO in March, 1964.

The Union had also been represented at several meetings of the Regional Offices of WHO: that of the Americas in Washington in 1963 by Mrs Tuller and Miss Gonzales; that of Europe by Dr Tottie; that of South Pacific at Bangkok by Dr Pierra Vejjabul in September, 1963. Mrs Force of the American Social Hygiene Association represented the Union at the Conference of the International Families Union held at Rio de Janeiro in July, 1963, and had presented a paper on the place of the school in family life education. Mrs Tuller had participated in the work of the Executive Committee of the UNICEF at Washington in June, 1963, and Dr Pierra Vejjabul had done so at Bangkok in January, 1964. Dr Tassi had represented the Union at the International Conference of Non-Governmental Organizations at Rome in April, 1964. Prof. Canaperia stressed the importance of the active participation of the Union at all these meetings. 
Relations with the World Health Organization had been excellent, and Prof. Canaperia thanked Dr Guthe and his colleagues for the help they had given the Union.

The Executive Committee of WHO had decided to deal each year with one major activity of the Organization in a particular field. Last year the problem of tuberculosis had been examined in detail and the International Union against Tuberculosis had been represented and had presented a statement.

It had been decided to devote the next session of the Executive Committee to the study of the problem of treponematoses and Dr Guthe had been called upon to present a report on this subject. The occasion would provide an excellent opportunity of drawing the attention of public health administrators and physicians to the necessity of intensifying efforts in the struggle against these infections. Prof. Canaperia thought it most important that the Union should be represented at this meeting of the Executive Committee and should present a statement.

Communications had been maintained with other international organizations such as the Social Committee of the United Nations, UNICEF, and CIOMS.

Prof. Canaperia was pleased to be able to inform the Committee that Eire, Senegal, and Hungary had joined the IUVDT, and he hoped soon to receive applications from other countries in the Near East with which he was in communication. There were only 15 new individual members, and it would be necessary to intensify the recruiting campaign.

In accordance with the decisions taken at the last meeting of the Executive Committee two new technical counsellors had been nominated: Prof. A. Basset, of Senegal, and Dr Alarçon of Venezuela. Prof. Canaperia was delighted to see that Dr Alarçon was present at the meeting and he anticipated that these new members would make important contributions to the work of the Union. Dr Basset had already achieved important results in French Africa and Dr Durel would present his report.

It had not been possible to organize other Regional Offices because of the local difficulties in setting up these organizations. Prof. Canaperia suggested that the Committee should name representatives of zones who could be responsible for collaboration with the Union, maintain contact with various countries to bring about the recruitment of new members, and establish a satisfactory liaison with the Secretariat of the Union.

The draft of by-laws had been prepared in French by the Secretariat and distributed to all members. Some copies in English had now been prepared for the English-speaking members.
In accordance with the decision taken in Copenhagen, the next General Assembly of the Union would be held in Lisbon in 1965. Prof. Canaperia had been in contact with Portuguese colleagues and extended greetings to Dr Norton-Brandao who was present at the meeting. His presence would prove most valuable for the preliminary discussions concerning the forthcoming General Assembly. With regard to the financial situation of the Union, $\mathrm{Dr}$ Tassi had done excellent work and he would present his report emphasizing the fact that the activities of the Union were curtailed by lack of financial resources. Prof. Canaperia hoped to have more secretarial help in the near future to help to intensify preparatory work for the next Assembly. The Executive Committee approved the Report of the Secretary-General and congratulated him on the extent and importance of his activities.

\section{(3) Report of the Director of the Regional OFFICE FOR EUROPE}

Dr Perdrup had taken part in the Symposium on Venereal Disease Control organized in Stockholm by WHO from September 24 to 28, 1963, and had presented a paper on "The Role of Non-Governmental Organizations in VD Control". Reprints of this paper had been distributed to all members of the Executive Committee. He represented the Union at a meeting organized by the Swedish Society for Social Workers in Copenhagen on May 5, 1963. The European Regional Office had been visited by representatives of different European countries; it had organized sessions for studying the behaviour of young people affected with venereal diseases which had been well attended. Two films had been bought in the USA, "The Innocent Party" and "Dance, Little Children". These had been shown to pupils of senior schools where Dr Perdrup had had the opportunity of exchanging opinions with these young people and of getting to know their points of view in the matter of sexual behaviour. A television programme had also been prepared for young people. Various journals and magazines had shown interest in the subject and had published articles about the struggle against venereal diseases. He proposed to conduct next autumn a follow-up conference for discussions with an organization of masters of high schools.

Finally Dr Perdrup was about to visit Thailand as an expert of the World Health Organization to advise the government of that country on methods for the control of venereal diseases.

The President congratulated Dr Perdrup on the activities of the European Regional Office. 
(4) Report of the Director of the Regional OFFICE FOR THE AMERICAS

In the absence of Mrs Tuller, Dr Webster gave a brief résumé of the report of the Director of the Regional Office for the Americas which had been prepared by Mrs Tuller and sent to all members of the Executive Committee before the Meeting.

\section{(5) TREASURER's RePORT}

Dr Tassi summarized the financial report, which had also been distributed to all members. He recalled that at the last Executive Committee it had been decided that member countries who had not paid their dues for three years should automatically be suspended from membership. This could be delayed at the discretion of the Secretary-General. Dr Tassi hoped that even after three years a member country would be permitted to continue membership by paying, if not the arrears, at any rate the subscription for the current year, and members of the Executive Committee were asked for approval of this suggestion. This proposal was accepted.

Dr Tassi appealed to the Regional Offices to help in stimulating member countries to pay their dues. He was happy to inform members of the Committee that the debt to Masson et Cie had been settled. The Editor had consented to a reduction in the amount owing for printing the report on "Non-gonococcal Urethritis". The President thanked Dr Tassi for his excellent work and members of the Committee expressed satisfaction at learning that the debt to Masson et $\mathrm{Cie}$ had been settled. A discussion followed on what should be done with the reprints which had not yet been distributed. Dr Durel said that a certain number of copies of "Non-Gonococcal Urethritis" would be kept in the archives of the Alfred Fournier Institute in Paris.

\section{(6) INDIVIdUAL MEMBERShIP}

A specimen brochure was passed round to members of the Committee. It had been prepared by the Secretariat and was intended for distribution to potential individual members. Another brochure had also been prepared by French members of the Committee. After discussion, the brochure prepared by the Secretariat was accepted in principle; it was decided to insert a detachable leaflet on which could be stated exactly how application should be made and the amount of the subscription. Dr. Durel agreed to add these modifications to the French text and undertook to send this to the Secretary-General.

Dr. Webster reminded members that Mrs Tuller had prepared a brochure in English which had been distributed widely in the USA. The President and the Secretary-General noted that the texts of the two brochures were very similar and suggested that there would be no objection to distributing different brochures in different countries.

As regards the rights and privileges of individual members, Prof. Canaperia stated that this question had been mentioned in Article I of the by-laws which he had prepared. In this article it was made clear that a preponderance of votes would go to member countries. There would be twenty votes for each member country and one vote for each individual member, in order to avoid the possibility of individual members establishing a majority when voting in the General Assembly. Dr Perdrup drew attention to the fact that in the financial report the Danish Association for the Struggle against the Venereal Diseases was not indicated as a paying member. He pointed out that the Danish Society did not pay dues to the Treasurer because it had made itself responsible for the expenses of the European Regional Office and the expenses of this amounted to more than the subscription which was due.

\section{(7) By-Laws}

Professor Canaperia presented documents he had prepared, apologizing for imperfections in the English translation which could not be corrected in the time available. The President asked the SecretaryGeneral to amend the English copy and send it to all members of the Committee for their comments. The final text would be presented for adoption at the next General Assembly. The Committee agreed that the decision as to voting rights outlined in Article I of the by-laws constituted an equitable arrangement.

\section{(8) Publications}

The second International Bulletin of the IUVDT had already been published in the British Journal of Venereal Diseases and would be sent to all members. Dr Durel reminded the Committee that the Bulletin de Prophylaxie Anti-Vénérienne would accept for publication all suitable papers relating to the problem of venereal diseases. Dr Alarçon asked whether the papers could be translated into Spanish. Dr Webster said that this matter would be discussed with Mrs Tuller; the Spanish text could not appear in the Bulletin of the Union, which was prepared only in French and English. Dr Alarçon said that it would be possible to publish in the Venezuelan medical press certain papers which might be sent to him. Dr King stated that the British Journal of Venereal Diseases would publish short statements of common international interest if they were sent to the Editor.

With regard to the publication of papers presented at the next General Assembly, Dr Nicol asked if Dr Laird would agree to publish them in English and in 
French. Dr Canaperia said that it would be necessary to publish them in the language in which they were delivered, with the addition of a short summary in English or in French; the Union was bilingual*.

\section{(9) Future Programme of the Union}

As regards the information sheets discussed at the last meeting of the Executive Committee, Prof. Canaperia, who had collected a certain number of these leaflets, said he would like to know how they should be used. After discussion it was decided that the Secretariat should request national organizations which were members of the Union to send leaflets and documents used in the anti-venereal services of their countries; these documents could be made available for examination at the General Assembly in Lisbon. In addition Dr Durel accepted the task of preparing a draft of an information sheet for patients with venereal disease to be presented at the General Assembly. At the Assembly an Italian specialist would prepare a résumé of documents designed for the education of the general public.

\section{(10) Resolutions ApProved by the LASt Assembly}

Prof. Canaperia reminded the Committee that two resolutions had been approved at the last General Assembly. The first concerned the preparation of a programme to be presented at the Assembly of WHO and this had been done. The second concerned recent health legislation adopted by different countries, the question of contact tracing, and an inquiry into epidemiological methods. As Dr Dumouloz, of WHO, had presented a paper on anti-venereal laws at the European Symposium of 1963 in Stockholm, the Executive Committee decided to wait until this paper had been published.

\section{(11) Relations With WHO}

Since the last meeting of the Executive Committee excellent relations had been maintained between the Union and the technical staff of WHO. Dr de Vries suggested that the Union might collaborate with WHO in a study of the teaching of venereology in medical schools. Dr King thanked Dr de Vries and re-affirmed the wish of the Union to collaborate closely with WHO. The question of teaching venereology in medical schools was one of the subjects which would be dealt with at the General Assembly in 1965.

* The President has discussed this question with the Editor of the British Journal of Venereal Diseases. Where papers read in French at Lisbon are concerned the journal will be able to publish only summaries in French. It is hoped that the Bulletin de Prophylaxie Anti-Vénérienne will be able to help authors who want to publish their papers in French.
The Union had it in mind to attempt to obtain information from its member countries by a simple, well-constructed questionnaire asking for information on this subject. It was suggested that $\mathrm{Dr}$ Webster should be asked to present suggestions for the construction of this questionnaire at the meeting on the following day.

Dr de Vries again expressed Dr Guthe's regret at not being able to be present at this meeting of the Committee; he recalled that the proceedings of the Symposium at Stockholm on VD Control would be published in five languages. The original in English had already appeared in the Bulletin of WHO. Dr de Vries stressed the interest of WHO in the health of adolescents and expressed the wish that the Union would give its own ideas on this important problem.

Dr Nicol and Dr Webster mentioned the publications on this subject that had appeared in their countries relating to venereal disease and young people. Dr de Vries said that WHO intended to buy copies of these publications. An article published in an American medical journal on the recrudescence of syphilis in recent years and results obtained in the control of this disease would be summarized in the Bulletin of WHO.

Dr Nicol spoke of research which had been proceeding on the sociological side of the problem. The results of this study would soon be published. Dr King said that the report on this study might be sent to Dr Guthe.

\section{(12) Future Meetings}

The President asked Dr Brandao to speak. Dr Brandao suggested, and it was so decided, that the dates of the General Assembly should be from April 26 to 30, 1965. Dr Brandao informed the Committee that a programme of work and of entertainment had already been studied by the Portuguese Committee. The meetings would take place at the Institute of Tropical Medicine and the programme of events had already been drawn up.

Dr Brandao was asked if it would be possible to arrange an exhibition of leaflets and other material for health education. He said he would do his best with the help of Madame Huet-Troue who had had past experience in such matters.

The programme committee would consist of Drs King, Nicol, Durel, Brandao, and Prof. Canaperia. Dr Webster undertook to prepare the questionnaire mentioned above after consulting with his colleagues in the USA and Dr Guthe. The draft of the questionnaire would then be submitted to the SecretaryGeneral. 
(13) Certificates of Merit

The proposal by the Secretary-General relating to certificates of merit was discussed by the Committee, and texts in French and English were approved. These certificates would be designed on the pattern decided at the last meeting of the Executive Committee and would be presented to the Specia Laboratories, Lovens Chemical Fabric, and May and Baker Ltd., as a sign of gratitude and appreciation for the generosity they had shown to the Union.

\section{(14) OTHER Business}

Dr Durel presented Dr Basset's report on the VD situation in various countries of West Africa which have close ties with France. Dr Alarçon also read an interesting report relating to venereal disease services in Venezuela. The President thanked Dr Basset and Dr Alarçon for their reports.

Dr Durel recalled that a study group for human trichomoniasis, of which he was President, had been established under the auspices of the Union seven years previously. He thought the time had come for someone else to take over this responsibility and suggested the name of Dr Feo, one of the VicePresidents, who was hoping to broaden the activities of this organization to cover the whole field of nongonococcal genital infections. The group is due to meet in Holland in June, 1965, and the Executive Committee decided to wait until this meeting had been held before approving the nomination of $\mathrm{Dr}$ Feo.

\section{TH GENERAL ASSEMBLY OF IUVDT}

The 24th General Assembly of the International Union against the Venereal Diseases and the Treponematoses will take place in Lisbon from April 26 to 29, 1965, and the President and Executive Committee take pleasure in extending an invitation to all members of the Union and colleagues and friends concerned with the problem of the control of venereal diseases and treponematoses to participate in the proceedings of the Assembly and in the technical conference which has been arranged for the same occasion.

In spite of continued medical progress in epidemiological methods and in techniques of diagnosis and treatment, venereal diseases have increased throughout the world and there is growing anxiety about this problem on the part of public health administrators and all those concerned with the control of venereal infections. The Union has an important role to play in the co-ordination of efforts in this field and discussions at the General Assembly in Lisbon will guide future policy and assist in devising methods of planning and strengthening the Union's programme of work.

In a statement which the Union had the privilege of presenting before the 34th session of the Executive Board of WHO in May, 1964, on the occasion of the review of the programme relating to venereal diseases and treponematoses, the views of the Union regarding the following essential activities were outlined:

(a) The promotion of medical education relating to venereology and the epidemiology of the venereal diseases.

(b) Intensification of epidemiological methods of casefinding and contact-tracing both nationally and internationally. (c) Detailed and systematic study of psychological and sociological aspects of human behaviour in relation to venereal diseases.

(d) Techniques of health education and methods of promoting their wider application.

(e) The stimulation of research, particularly into medical and sociological aspects of these problems.

All these matters are on the agenda for the meeting in Lisbon. The first session of the conference will be devoted to the problems of education. It is obvious that no control programme is possible without the full collaboration of the medical profession and the extent of the profession's support will depend on the standards of teaching of the subject to both undergraduate and postgraduate students. The IUVDT in collaboration with WHO, is undertaking a joint survey on the teaching of venereology in medical schools, and the results of the study will be presented to the Assembly by Dr Bruce Webster. By giving special emphasis to the problem of medical education the Union hopes to gain valuable information as to the present situation in different countries and to formulate proposals which will lead to a better understanding of these problems among members of the medical profession. Two other related problems will be on the agenda-namely, the education of the patient, and the education of the public.

An exhibition of educational material will be organized during the conference, and we invite all our members to send any material which may be available in their respective countries (posters, leaflets, instructions, film-strips, films, etc.) to the organizing committee in Lisbon.

The second session will deal with the social and behavioural trends which lead to promiscuity and to the spread of venereal diseases. The rising incidence 
of venereal diseases is in fact a symptom of a far larger problem of social illness characterized by a disruption of family life, changes of moral outlook, and an increase in promiscuity among young people.

Voluntary organizations have a very important role to play in this field, and reports and studies on the various factors which influence the pattern of human behaviour and its effect on the incidence of venereal diseases will be welcomed.

The agenda for other sessions includes a review of basic research work in the field of venereal diseases and treponematoses, in which it is intended to place necessary emphasis on some of the vital problems which are still unsolved, and thus to mobilize all resources for combating the challenge which these diseases present.

The Union is very appreciative of the support that WHO has given to its various activities, support generously given in the spirit of close and harmonious co-operation which has always existed between the two organizations. There is no doubt that the integration of official and voluntary efforts is essential to the success of efforts to control venereal diseases.

The Executive Committee and all the delegates are delighted to have the opportunity of meeting Portuguese colleagues on their own ground in Lisbon and would like to express their deep gratitude to the Portuguese Organizing Committee, which has been so helpful in the planning of the conference and has undertaken the heavy task of the organization of the meeting.

The Committee is confident that all member countries will participate in sending delegates to this important meeting and that many individual members and others who are interested will attend. The exchange of views and experiences among the delegates will ensure the success of the conference and lead to an increase of national and international efforts for the control and elimination of the venereal diseases and treponematoses.

\section{STATEMENT OF THE IUVDT TO WHO EXECUTIVE BOARD, 1964}

This statement, made by Dr G. Tassi on behalf of the International Union against the Venereal Diseases and the Treponematoses, is a programme review on the subject of the venereal diseases and endemic treponematoses.

"Thank you very much, Mr Chairman, for allowing me to make a statement on behalf of the IUVDT. May I first take the pleasure of transmitting to the Director-General and the Organization the greetings of the President of the IUVDT, Dr A. J. King, of London, and its Secretary-General, Professor Canaperia, who regrets he cannot be present.

"The Director-General of WHO has considered it appropriate to choose, for the programme review at this session of the Board, the problem of 'Endemic Treponematoses and Venereal Infections'. In making this choice, we believe that the Director-General was guided by two considerations: the first, that in spite of continuing medical progress in diagnosis, treatment, and public health control measures, there has been in the latest years a world-wide recrudescence of venereal diseases, and particularly of syphilis; second, that this problem should again be recognized as a major public health problem and that national and international efforts should be intensified for an efficient control and, possibly, elimination of these diseases.

"The IUVDT may claim the merit of having repeatedly, during these recent years, issued warnings against the too optimistic idea prevailing among some medical men and health administrations that venereal diseases were no longer a real danger and that the budgets and the organizational structure for their control could therefore be greatly reduced. It is gratifying to note that there is, at present, in many countries, a re-awakening of concern for the continuing rising incidence of early syphilis and gonorrhoea, and the very clear, comprehensive, and detailed study presented by the Director-General to this session of the Executive Board is not only an excellent review of the work done in this field by WHO, but also a challenge for the need of more determined public health efforts nationally and internationally."

Dr Tassi then spoke of the gratification of the Union at the close co-operation between WHO and itself since 1948 and outlined some of the beneficial effects of this collaboration. He spoke of the reorganization of the Union and reviewed some of the recent activities. He described the special problems which exist in the field of venereal diseases and treponematoses and mentioned that these problems would be discussed at the forthcoming General Assembly of the Union in Lisbon in April, 1965. He continued as follows:

“... the IUVDT feels that, in the present situation, national and international action should be intensified, with a very close co-operation of official and voluntary organizations. The Union is ready to take its share in this work and will continue to give its full support to the activities of WHO." 